\title{
Healthy Cities, New Technologies and Sustainability: A Collaborative Mapping of Informal Sport Activity in the Public Space of Cities as an Innovative Tool for Understanding City Sport Phenomena
}

\author{
Marta Cornax-Martín ${ }^{1}$, Nuria Nebot-Gómez de Salazar ${ }^{2, *}$, Carlos Rosa-Jiménez ${ }^{3}$ (1) \\ and Ana Luque-Gil ${ }^{4}$ \\ 1 Chair of Emerging Technologies Citizenship, University of Malaga, Av. de Cervantes, 2, 29016 Málaga, Spain; \\ martacornax@gmail.com \\ 2 School of Architecture, University of Málaga, El Ejido University Campus, Plaza El Ejido, 2, 29013 Málaga, Spain \\ 3 Institute of Habitat, Tourism and Territory, School of Architecture, University of Malaga, El Ejido University \\ Campus, Plaza El Ejido, 2, 29013 Málaga, Spain; cjrosa@uma.es \\ 4 Faculty of Tourism, University of Malaga, Teatinos University Campus, Calle León Tolstoi, 4, 29071 Málaga, \\ Spain; geoana@uma.es \\ * Correspondence: nurianebot@uma.es
}

Received: 23 July 2020; Accepted: 29 September 2020; Published: 3 October 2020

check for updates

\begin{abstract}
Urban public space has become one of the main infrastructures for informal sports in cities. However, despite the high impact of that practice, local records only show the sports activity at the urban spaces specifically designed and regulated for that purpose. More information about where this practice arises and what attributes of urban space promote it would allow the adoption of specific measures in urban and sports policies. This paper proposes a methodology mainly based on the mapping of this informal sport activity and urban places where it appears by local communities and sportspeople. These collaborative maps are supported by the use of geographical information system (GIS) technologies and surveys on local communities. The research establishes a double objective of identifying urban spaces where citizens perform outdoor sports and deepen the knowledge of the physical attributes of public spaces that promote sports and local demands related to public space requirements. This methodology has been tested in the city of Malaga, the European City of Sport 2020, as a reference of a city with a growing outdoors' sport activity. The main contribution is focused on the use of new tools that offer subjective information: opinions and habits of citizens in relation to sport urban practice. This information-which is difficult to obtain through other resources-should be considered for the design of urban and sports policies according to citizens' demands.
\end{abstract}

Keywords: public space; informal sports activity; collaborative mapping; geographic information systems (GIS), surveys on local communities; webGIS digital platform; sustainability

\section{Introduction}

Urban public space has become, in recent years, one of the main infrastructures for informal sports and physical activity in cities. Informal sport is considered to be that which is practiced outside those spaces specifically designated for the practice of sport activity; beaches, parks, riverbeds, mountains, streets, squares, etc. are environments that many people choose to practice outdoor sports [1]. This research is interested in the informal sports activity that arises spontaneously and unplanned in public spaces that, without being spaces designed for sports, have attributes and qualities that promote such practice. On the other hand, formal sports activity refers to what occurs in urban spaces designed 
for the practice of a specific sport, such as swimming pools, soccer courts, basketball courts, sports facilities in urban parks, etc. [2]

However, the reality of what is occurring in cities and the practice of sports in the urban space is much wider. In Spain, statewide sporting habits surveys [3] showed that $45.9 \%$ of people that practice sports prefer to do it outdoors. It is important to establish the reality of each city-its physical structure, its urban spaces, demands of local communities, etc.-in order to propose strategies and measures to foster an active life there. This has all led to a field of research of great scientific interest that delves into the relationship between public space, urban design, health and promoting physical activity [4]. However, there are very few studies focused on studying and measuring informal physical activity that allows that relationship to be expounded on [5], and where new technologies provide opportunities to discover the dimension of that informal practice in urban settings $[4,6]$.

This type of research is even more necessary given the lack of policies highlighting the unquestionable relationship between urban planning and health [2]. The case of England stands out in Europe as there is an entity within its National Health System, the London Healthy Urban Development Unit, dedicated to the specific study of sustainable urban development [7]. In Spain, special mention should be made of initiatives such as the one by the Barcelona Global Health Institute with its Urban Planning, Environment and Health study, whose aim is to consider tools and indicators to foster healthy urban development [8]. Other cities, such as Valencia [9] and Granada [10], have driven sports strategic policies that include studying urban spaces and areas of the cities favorable for practicing sports.

This paper proposes and tests a methodology based on the mapping of this informal sport activity and urban places where it appears by local communities and sportspeople. These collaborative maps are supported by the use of geographical information system (GIS) technologies and surveys on local communities. The research establishes the double objective of identifying urban spaces where citizens perform outdoor sports, and deepen the knowledge of the physical attributes of public spaces that promote sports and local demands in relation to public space requirements. The main contribution is focused on the combined use of new tools-collaborative mapping - that offer subjective information on the different kind of places chosen by local communities, opinions and habits of citizens in relation to sport practice. This information is difficult to obtain throughout other resources, but it is necessary in order to be considered for the design of urban and sports policies according to citizens' demands.

\section{State of Play}

The World Health Organization has established a direct relationship between a healthy and active city, the social cohesion of its communities and urban public space [11]. Some of the research delving into the study of the urban space as a generator of social relations and trigger of informal practicing of sport is considered below. Research related to the use of new information and communication technologies as a tool to incentivize physical exercise in urban settings is likewise reviewed.

\subsection{Urban Public Space as a Generator of Social Relation and Practising Sport}

Public space is one of the best and most appropriate places for sports activities in their most social and inclusive aspect [12]. However, before going further in that regard, some comments need to be made regarding what public space is considered to be. From a legal perspective, public space is taken to be open access places, in other words, those that are available to any citizen. However, it should be noted that there is a difference between public space and collective space [13], where the collective public space is a space where there is a right of admission even though it is public, in other words, where there is a fee or some type of control of the use. Many of the spaces considered to be public often have fences or railings where its status of public space is increasingly being eroded and they are beginning to be places that are gradually becoming more controlled and compartmentalized. That condition may contribute to reducing the diversity of uses that local communities make of the urban space. 
One of the main problems of contemporary cities is the shrinkage and lack of social relations in the public space [14]. Recreational activities in urban spaces help to increase the diversity of uses, safety, number of experiences and life of a street, neighborhood or a square. The studies conducted by Gehl [15] in which he analyses the key aspects of urban design to foster social relations and life in community "between buildings" are of great interest. Kostrzewska [16] also calls for a minimum quality of amenities and urban public space for the proper development of recreational activities and social life in the city. All those studies agree with the importance of urban design and planning to foster relations and ties of identity among the people of a community and with their immediate environment, and thus, to guarantee the appropriation and care of the urban space by the citizens.

The emotional relationships between people and places cover a wide range of physical settings and emotions [17]. From the psychological perspective, appropriation is defined as "a basic mechanism of human development, because the person "appropriates" the widespread experience of the human being" [18]. The appropriation of those spaces, according to Fonseca Rodríguez [19], consists of taking the public spaces or cities for a sports or cultural activity that generates a manifestation of individual and collective practices in places that have not necessarily been designed for that activity. In any event, as Magrinyà and Mayorga indicated [13], spaces where there is an existing use or appropriation (of the street furniture for example) by the neighborhood are living public spaces. However, those where that activity does not occur may be neglected and abandoned places as they are non-experienced spaces [20]. Hence the importance of working on the identity relationship between local communities and their physical environment.

Nieto [21] uses the term "territoriality" in her study when referring to the generated feeling of appropriation by people of those places. According to Camino et al. [22], urban space become genuine social generators when they allow different activities to be carried out, including sports activities, as they meet the appropriate conditions, thus become true social generators that contribute to a cohesion among citizens and to better quality of life of the users.

It should be noted that, in the same way as for other activities in the public space, sports activity leads to changes to the public space, thus becoming a container of different activities and mix of uses. Sports events held occasionally are also specific moments when citizens are encouraged to actively participate in sports activities. Those events, which are always short in length, generate a significant bond to the space both for the residents and for non-residents [23].

All that research shows how urban public spaces and the design of the settings can incentivize, to a greater or lesser extent depending on their characteristics, the promotion of physical activity in the city. In some of these investigations, specific aspects of urban design are related, such as sidewalks, pedestrian zones, bicycle facilities, factors affecting intersection quality (e.g., crosswalks, pedestrian signals and traffic calming) among others [24]. Magrinyà and Mayorga [13] considered the role of park infrastructures as planned spaces associated to sports, the roles of streets as generators of informal sports practices and of how private sports amenities attract nearby sports spaces. The emergence of non-formal and formal sports practices that coexist in the same place where the design is based on tolerance, rather than the exclusion of undesirable behaviors, such as some sports prohibitions in certain parks, seems to encourage sports practice [16].

There are high number of studies of natural settings as spaces that foster physical activity and sports. A study conducted by Kaczynski and Henderson [25] showed that proximity to parks and paths were associated to an increase in physical activity. In this regard, Wheeler et al. [26] found that the activity levels of children living near to green areas was more intense than of those living further away. The research of Marselle, Irvine and Warber [27] shows that the benefits of walking in groups in natural settings are greater than doing so in urban spaces. It can therefore be concluded that natural settings lead to less perceived stress and greater mental and emotional wellbeing [28]. Therefore, in the cities and more urbanized settings, public green spaces play key roles in promoting health and wellbeing [29]. 
When we are talking about natural setting, we are also referring to the marine environment and coastal areas. According to a study conducted in the cities of Barcelona and of Bilbao [30], the reasons why waterfronts are used for sports are related to two main aspects: the characteristics of the setting and its proximity to the waterfront. In the case of Barcelona, for example, $25.2 \%$ preferred its location given its proximity to the waterfront and $65.4 \%$ stressed the characteristics of the setting, whether the closeness to the sea, the lack of pollution or free-to-use sports equipment. The percentages were similar in the case of Bilbao: $31.9 \%$ and $67.6 \%$, respectively.

This research delves into the urban design parameters that favor the informal practice of sport and physical exercise in the line of previous research, providing a novel approach based on the way of accessing information provided by citizens through collaborative mapping and surveys. Besides, as Koosarhi [4] indicated, the majority of research focuses on studying natural areas and noted the need to study other types of public spaces that are not parks or green zones-streets or squares, for example-which can also contribute to encouraging practicing sports in cities. In that regard, this paper proposes a methodology to map informal sports and physical activity in different types of urban settings: natural areas or other more urbanized ones that allow key aspects to be considered in the urban design of different types of public spaces.

Furthermore, little research has so far delved into the methods of measuring sports and physical activity in specific settings and contexts, but rather it has used very general systems to measure physical activity [31]. Koosarhi [4] explains how using global measurements limits the understanding of the amount of physical activity in urban settings and highlights some specific research that uses combined measurements methods such as accelerometers, sensors and geolocation systems [6]. In that regard, new technologies provide new opportunities to explore, to measure and discover the reality of informal physical activity in urban settings.

\subsection{The Role of New Technologies When Promoting Sport Activity in the City}

Internet and the new information and communication technologies have become a tool that allows projects to be developed to educate in values through sport, whether as an educational medium or as a means of communication [32]. There are numerous studies researching mobile applications that seek to foster sports activity with large increases in usage rates since their introduction in 2007 [33,34]. The work of Hosseinpour and Terlutter [33] makes an updated review of research on mobile phone applications which foster physical activity, and delves into the different app techniques in order to determine their effectiveness: self-monitoring, goal setting, competition, social sharing or rewards. In many cases, several strategies are combined, as described in the following examples.

In the case of the Walk @ Work app (promoted by Leeds Metropolitan University, UK and Queensland University, Australia), positive results were obtained assessing the workday step count of lower-activity employees by using an automated web-based walking intervention. Goal setting and social sharing techniques have been used in this case [35]. Another study into the Runtastic app for runners, defined as a health and fitness community [36], researched into how the platform coordinates both the mobile app and the Facebook social media, thus revealing its main use to achieve targets and improve enjoyment of physical activity by social sharing. In addition, many of these app work as locative social media networks that allow users to know the preference of using a certain place [37]. This research work uses a locative social web-platform to encourage physical activity in the public space of cities.

Step counters are another technological tool that encourages the population to get active and significantly lead to a reduction in body mass index and blood pressure [38]. Yet the greatest potential lies in the mobile devices given their wide use among the adult population $[39,40]$. This smart medium allows the public's physical activity to be recognized thanks to the incorporation of three specific sensors: tri-accelerometer, gyroscope and magnetic sensor [41]. The aim is to use the accelerometer to achieve a monitoring system for health purposes [42]. 
According to Lau et al. [43], Internet and mobile phones have provided an important and powerful channel to encourage children and adolescents to be active. Women, on the other hand, are the most sedentary sector of the population, and it has been shown that their activity level can be increased using step counters and mobile phones [43,44]. The study by Arteaga et al. [45] explored the design requirements for mobile games in order to encourage adolescents to do exercise, including multi-player abilities.

Koosarhi et al. [4] highlighted the opportunity of the new technologies as a means to discover and measure sports activity in urban spaces. Increasingly, citizens share information on social networks about new routes or places where they choose to carry out their sporting activity, due to their appropriate physical characteristics [46]. This information on the kind of use that citizens make of public space, needs and preferences, should be considered in the decision making process by local authorities. Thanks to collaborative platforms and applications, such as Strava (social network based on Internet and Global Positioning System, focused on sportspeople, cyclists and runners) and Endomondo (sports motivation web platform), a database has been generated that provides information on sports users in the city. For example, data on common informal routes within the city are contributed by runners, cyclists, swimmers, etc. It is a powerful source of information as increasingly more users are taking part in those web platforms.

The global positioning systems (GPS) have become a measurement tool with great potential $[6,47]$ to recognize the physical locations of sports activity in cities. In the case of the study by Liao et al. [48], GPS was used to observe the relationship between population density and the connectivity of streets with greater time dedicated to walking and doing exercise.

All these applications and technologies are encompassed in the eHealth or mHealth concept coined by Robert Istepanian [49] as the use of "emerging mobile communications and network technologies for healthcare", with healthy habits such as sports coming into play [50].

In the field of Urbanism and Urban Planning, Geographic information systems (GIS) are a fundamental tool for urban development. In the case of the study by Kulawiak and Lubniewski [51] they study how the design of a GIS tool can provide information about municipal critical infrastructures through objective analysis, simulations and spatial analysis. The physical activities registered online thanks to the locative data applications are an important sample of the "physical footprint" of people's activity in the city [37], being very valuable information for urban and social administrations and local administrations with sports competencies. The contribution of this research is not so much technological but the construction of a cartography - through collaborative mapping - that allows to understand where informal sports are practiced in the city and which urban areas promote them and vice versa. The digital platform, based on the use of GIS, has been created as a tool that enables this collaborative mapping.

\section{Methodology}

This paper proposes and tests a methodology based on the mapping of informal sport activity and urban places where it appears by local communities and sportspeople. These maps are supported by the use of a webGIS digital platform and surveys made on citizens and local administrations. All these tools have been tested in the city of Malaga with the double objective of identifying urban spaces where citizens perform outdoor sports, and deepen the knowledge of the physical attributes of public spaces that promote sports and healthy habits, as well as local demands in relation to public space requirements.

The use of a webGIS digital platform—designed and executed specifically for the research project Málaga Activa (see Acknowledgments section)—has allowed mapping and geolocating the urban areas where outdoor sports are carried out in the city. These mapping of physical activity has been made by citizens thanks to the use of the mentioned digital platform. The surveys carried out on citizens and local administrations have also allowed an in-depth study of the attributes and qualities of the urban 
space that promote sport, the most requested demands by the local population and trends in emerging sports modalities.

\subsection{Phase 0. Construction of the Digital webGIS Platform}

A website [52] has been designed and executed with a GIS system that has allowed the introduction of information and data by citizens, in a geolocated and real-time manner and, consequently, the collaborative mapping of the different initiatives and sports activities of local communities. This digital platform or any other similar one can be used in any city or urban area where the study of sports activity in the urban space wants to be implemented. The dissemination of this website through social networks and local media, such as radio and television, has allowed its use by the user community. The digital platform is the tool that has allowed, on the one hand, to collect all the information about informal sports activity on the public space, and on the other hand, it has made it possible to show, graphically and geo-referenced this information and its dissemination among citizens.

The platform architecture includes the following parts and technologies:

- Frontend: Application implemented through the Javascript React libraryand Mapbox Platform (open source) for the creation and management of maps and georeferenced information.

- Backend: Use of the Google Firebase platform, specifically: Firebase Authentication (for user authentication) Cloud Firestore (database for storage of initiatives) and Cloud Storage (for storage of initiative images).

\subsection{Phase 1. Collection of Objective Information for its Subsequent Loading on the Digital Platform}

This first phase consisted of analysis using the existing documentation provided by documentary information sources and by local institutions, along with a citizen participation process:

- Planimetric consultation of existing sports facilities in public spaces where sports take place, parks and natural areas [53]. Cataloguing urban areas where non-formal and formal sports take place using the information provided by different local authority services through interviews. A committee of experts from different institutional areas was therefore set up. The results of these interviews are registered in Table 1.

- Semi-structured interviews with the management areas of the different neighborhoods or districts (citizen participation process).

- Compiling information in the databases of the existing virtual resources (web platforms used by sportspeople like Strava [54] and Endomondo [55]) that are most used and highest rated by users. 
Table 1. Concentration of informal sports activity. The 17 urban spaces identified in the table are the result of the analysis of the information provided by the different agents surveyed. Each of them has been asked to identify different urban areas and/or public spaces with informal sports activities. Those spaces have been selected to conduct interviews with sportspeople and their direct observation. Source: prepared by the authors.

\begin{tabular}{|c|c|c|c|c|c|}
\hline \multirow[b]{2}{*}{ Urban Public Space * } & \multicolumn{5}{|c|}{ Reporting Agents } \\
\hline & $\begin{array}{l}\text { Malaga Town Planning } \\
\text { Department and Urban } \\
\text { Environment Observatory }\end{array}$ & $\begin{array}{l}\text { Malaga City } \\
\text { Council } \\
\text { (Sports Area) }\end{array}$ & $\begin{array}{l}\text { Blanquerna } \\
\text { Univ. Research }\end{array}$ & $\begin{array}{c}\text { Reporting } \\
\text { Agents for } \\
\text { Each Sports } \\
\text { Type } \\
\end{array}$ & $\begin{array}{c}\text { Sports } \\
\text { Applications } \\
\text { (Straba and } \\
\text { Endomondo) }\end{array}$ \\
\hline $\begin{array}{l}\text { 1. Natural channels } \\
\text { (Guadalhorce riverestuary) }\end{array}$ & $\mathrm{x}$ & $\mathrm{x}$ & & & $\mathrm{x}$ \\
\hline $\begin{array}{l}\text { 2. Big parks and green areas (Maria } \\
\text { Luisa Park) }\end{array}$ & & $\mathrm{x}$ & & & \\
\hline $\begin{array}{l}\text { 3. Big parks and green areas } \\
\text { (Litoral Park) }\end{array}$ & & & & & $\mathrm{x}$ \\
\hline $\begin{array}{l}\text { 4. Big parks and green areas } \\
\text { (Oeste Park) }\end{array}$ & $\mathrm{x}$ & $\mathrm{x}$ & & & $\mathrm{x}$ \\
\hline $\begin{array}{l}\text { 5. Big parks and green areas } \\
\text { (Huelin Park) }\end{array}$ & $\mathrm{x}$ & $\mathrm{x}$ & $\mathrm{x}$ & $\mathrm{x}$ & $\mathrm{x}$ \\
\hline 6. Seafront (Huelin waterfront) & $\mathrm{x}$ & $\mathrm{x}$ & $\mathrm{x}$ & & $\mathrm{x}$ \\
\hline 7. Seafront (La Misericordia waterfront) & $\mathrm{x}$ & $\mathrm{x}$ & $\mathrm{x}$ & & $\mathrm{x}$ \\
\hline 8. Sefront (Torre Mónica waterfront) & $\mathrm{x}$ & $\mathrm{x}$ & & & $\mathrm{x}$ \\
\hline $\begin{array}{l}\text { 9. Channeled channels near areas of } \\
\text { centrality (River } \\
\text { Guadalmedina estuary) }\end{array}$ & $\mathrm{x}$ & $\mathrm{x}$ & & & $\mathrm{x}$ \\
\hline $\begin{array}{l}\text { 10. Squares near áreas of centrality } \\
\text { La Marina Square }\end{array}$ & $\mathrm{x}$ & $\mathrm{x}$ & & $\mathrm{x}$ & \\
\hline 11. Seafront (La Malagueta waterfront) & $\mathrm{x}$ & $\mathrm{x}$ & $\mathrm{x}$ & $\mathrm{x}$ & $\mathrm{x}$ \\
\hline $\begin{array}{l}\text { 12. Seafront (Baños del } \\
\text { Carmen waterfront) }\end{array}$ & $\mathrm{x}$ & $\mathrm{x}$ & & $\mathrm{x}$ & $\mathrm{x}$ \\
\hline 13. Seafront (Pedregalejo waterfront) & $\mathrm{x}$ & $\mathrm{x}$ & & $x$ & $\mathrm{x}$ \\
\hline 14. Seafront (El Palo waterfront) & & & & $\mathrm{x}$ & $\mathrm{x}$ \\
\hline 15. Seafront (El Dedo waterfront) & & & & $x$ & $x$ \\
\hline $\begin{array}{l}\text { 16. Big parks and green areas (El } \\
\text { Morlaco Park) }\end{array}$ & & & & $\mathrm{x}$ & $\mathrm{x}$ \\
\hline $\begin{array}{l}\text { 17. Big parks and green areas (Montes } \\
\text { de Málaga natural park). }\end{array}$ & $\mathrm{x}$ & $\mathrm{x}$ & & $\mathrm{x}$ & \\
\hline 18. Teatinos area ** & & & & & \\
\hline
\end{tabular}

\subsection{Phase 2. Collection of Subjective Information for its Subsequent Loading on the Digital Platform.} Observation and Surveys of Citizens

An analysis based on an approach using more experiential methods in order to map sports practices from a phenomenological analysis and considering subjective and perceptive aspects. The aim is to map informal initiatives not entered in more conventional databases. This process consists of the different sub-phases:

- Direct observation of the urban spaces with greatest sports activity or interest identified in the prior analysis.

- Creation of observation datasheets for each place, where the observer fills in the information on the zone, along with taking photographs of different activities in different weather and times of the day.

- $\quad$ Surveys on users of the urban space and sportspeople (citizen participation process). The aim of those surveys is focused on checking the prior analysis, in addition to being able to obtain additional information on the attributes and values of those spaces, and information on the state of repair of those spaces and aspects to be improved there. The survey form is included in an attached document. 
- Setting up of a committee of agents reporting on the different sports identified; those agents are sports entities or associations and other individual sportspeople who use the urban space for a specific activity from the following: volleyball, surfing, parkour, rowing, running, skateboarding, roller skating, wellness, free-style bicycles, cycling and swimming. This committee allows greater knowledge to be obtained on informal sports activity as per the different sports.

- An online survey where information is obtained from the users of the public space for sports. Information is obtained on their preferences, opinions and suggestions regarding those spaces. The survey collects information about the respondents (sex, age and country of origin) as well as information regarding their sports practice habits in the urban space, their preferences, opinions and demands regarding infrastructure requirements and conditions of urban space. From this link the online survey carried out can be accessed: online survey.

\subsection{Phase 4. COLLABORATIVE MAPPING. Loading of Information on the Digital Platform and} Simultaneous Dissemination of the Platform on Social Networks and Local Media to Involve Citizens in the Process of Mapping Sports Information in the City

From the information collected in the previous phases, the different sports initiatives identified in the urban space of the city are mapped through the use of the digital platform. Likewise, the platform allows the adding of detailed information on each initiative (in addition to the place where it is located, the time it is carried out, a complete description of the activity, an image of it, and possible improvements to the urban space that promote sports practice). The loading of information on the platform can be done by the users or athletes themselves who locate and map their activity, either by indicating an address, or by placing it directly on the city map. Likewise, the research technicians are also be able to map the activity of the surveyed users based on the information provided by them.

\subsection{Case Study: City of Malaga}

The aforementioned methodology has been tested in the Spanish coastal city of Malaga, European City of Sport 2020 and a benchmark city with a growing sporting activity. According to studies conducted in 2016 on sports activity on the east and west promenades of the province, there was a $42 \%$ increase in sports activity compared to the previous study conducted in 2013-2014. The optimal climatic conditions and the presence of a linear coastal promenade in almost the entire capital favor the sporting activity of physical exercise outdoors throughout almost the whole year. However, despite the high impact of informal physical activity in certain areas of the city, there is no public information recorded about the environments with greater informal sports practice, what type of urban spaces favor sports, or on the contrary, they inhibit it.

\section{Discussion and Results}

\subsection{Tool to Recognize Health Status. Methodology to Map the Sport Activity in the City}

In the implementation and testing of the proposed methodology, all phases have been completed. This paper shows the first results set out below. In addition, special mention must be made of the construction of the webGIS digital platform, as a very useful tool to map informal and formal sports activity made by citizens (see Figure 1). 


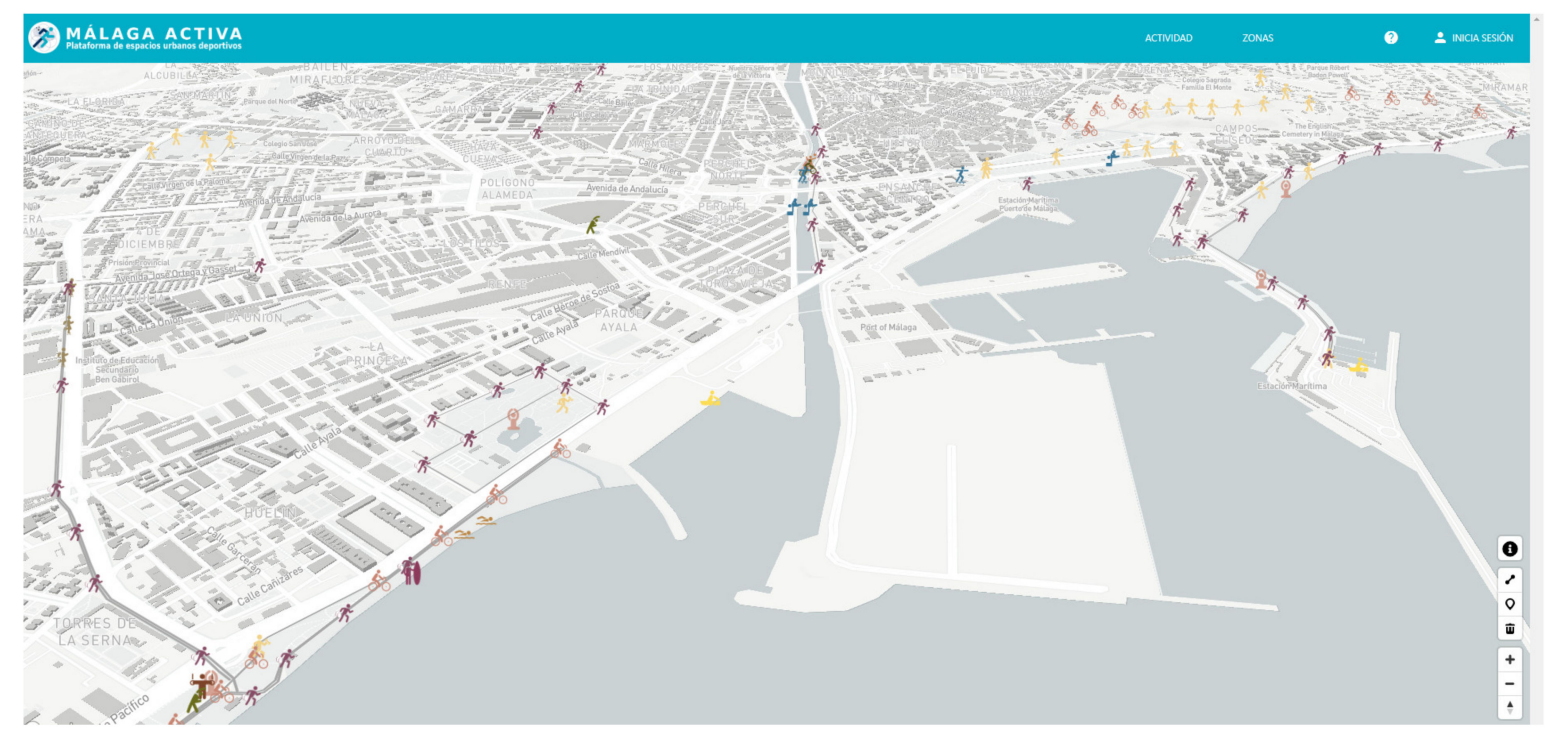

Figure 1. Activa Málaga webGIS digital platform [52]. It lets citizens to map their sport activity in the city.

This digital tool has become a very useful tool to map and locate the different initiatives related to physical activity and exercise in the urban space. Firstly, it has allowed to show the data recording and identification process to the citizens, which turns this methodological approach into an open process-addressing the different sports types and demands-and in constant transformation. The platform is updated by the users themselves, thus providing real information that is always up to date. Although it is not real time GPS application, users upload an updated information about places to practice sports in the city. This allows knowing what is happening in the city in a real way and adjusted to opinions and citizen demands.

Secondly, as it is an open digital platform, it has been a consultation tool which also encourages users to do physical activity, as is the case of other e-health applications.

The list of potential stakeholders in this study, and especially for the use of the platform, includes sports people from different sports disciplines interested in knowing appropriate urban spaces for the practice of a certain sport or exchanging information with other people; citizens who, without being athletes, want to carry out some activity or physical exercise outdoors for health reasons, such as the elderly or children; technicians from local administrations who access a type of information that is difficult to obtain on physical activity, habits and demands of local communities and which is essential to encourage an active and healthy life through sports and urban policies; researchers in the study of the relationships between the city, attributes of public space and sports.

Thanks to the Google Analytics extension, the impact of the platform can be observed. In 10 months of activity, there are a total of 240 users. A total of $75 \%$ access through computers and $25 \%$ use mobile phones to access the platform. The point of greatest use of the platform occurred in the months of May and June 2020 (with an average of 60 users per month). It coincides with the end of confinement in homes due to COVID-19, something that will have to be contrasted with medium-term results.

One of the main difficulties found is related to the dissemination and the use of the platform by users; the success of the tool itself depends on the number of people using it: the larger the number of entries, the more complete the information is, and probably, more attractive and useful for the general public. In the phase 4, Collaborative Mapping, a limited number of entries by citizens have 
been achieved, as an established dissemination plan could not be completed, and which has been carried out later. However, there are sufficient number of users to reach some initial conclusions. In addition, the greater number of entries were obtained from data in the different stages defined in the methodology, using experiential and objective sources. It is therefore important to indicate that the different information sources are complementary; field work (interviews, existing digital platforms, direct observation, etc.) does not replace the information gathered by the users of the digital platform, but they complement one each other.

Likewise, the graphic representation and location of the physical activity provide some data of interest about what is occurring in the city: which are the most active areas and greater concentration of sports activity. These could be understood as healthy neighborhoods. The digital platform shows how in the study area, numerous citizens chose the waterfront along the whole coast, both to the east and to the west, to do sports. Due to its linear nature and pleasant settings, numerous formal (bodybuilding and calisthenics circuits, bike lanes, etc.) and non-formal (running, roller-skating, power walking, beach volleyball, etc.) activities make this sea promenade a main sports hub.

The existing difference between those sports spaces in the non-formal and formal public urban setting reveals two main lines of study. Firstly, the study of those formal sports spaces that are catalogued by local administration in databases that can be freely accessed by the citizens [53]. The way of analyzing those spaces is focused on the observation of their use or the state of the specific infrastructure. In the majority of cases, they are facilities (football pitches, basketball courts, bodybuilding circuits, etc.) designed in the same way, regardless of their setting as indicated in the research by Magrinyà and Mayorga [13]. Secondly, in the case of non-formal sports areas, it is of interest to establish the selection criteria of the users, the characteristics and attributes of the setting that make those areas more attractive for sportspeople, following the same line as Gil [56].

\subsection{Healthy Neighborhoods. Identificación of Areas of Concentration of Informal Sports Activity}

A series of sports hotspots that can be grouped into a total of four main areas (see Figure 2) has been obtained from studying the informal physical activity in the city, by means of the data provided by the web platforms analyzed (Straba, Endomondo and Activa Málaga) and that obtained from the reporting agents (stakeholders of the Malaga City Council administration and reporting agents for each sport chosen).

The following areas of sports concentration can be highlighted: (1) coastal shoreline, (2) mouth of natural channels such as the River Guadalhorce, (3) natural surroundings and large green areas such as the Montes de Málaga natural park and (4) channeled riverbeds near central urban environments like the course of the River Guadalmedina. The three first study areas have their proximity to a natural place. As in much of the earlier research, the role of natural settings as generators of informal sports activity is highlighted. In turn, those are divided into two categories: the spaces close to the marine environment (coastal shoreline and mouth of the River Guadalhorce); and the spaces near to a natural green area (Montes de Málaga natural park and the course of the River Guadalhorce).

Likewise, some spaces have been identified in urbanized—non-natural-environments, such as the case of the course of the River Guadalmedina, as it is a river channeled by retaining walls and constructions. It is an urbanized space that has lost its main function of transporting water as the bed is empty most of the year. Some individual or social groups use its linearity and situation (next to the old town of the city of Malaga) for informal sports. That space has, thus, been appropriated by the citizens and a new identity of the place has been created for its users. 


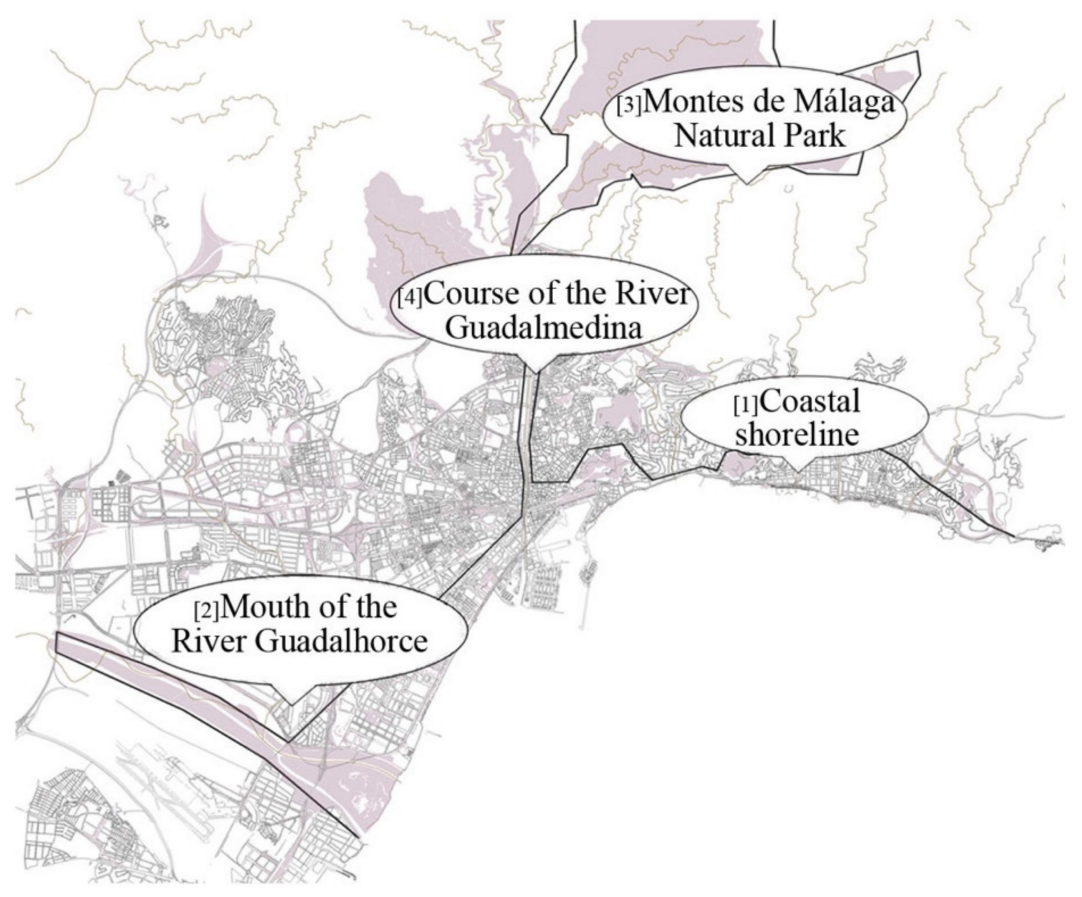

Figure 2. Areas of informal sports concentration in the city of Malaga. Source: prepared by the authors from data provided by the different agents surveyed.

In addition to these four concentration areas of informal sports activities, the parks or green areas with general sports facilities are also considered as the main points of coexistence between formal and informal physical activities, following the findings of Magrinyà and Mayorga [13]. From all these results, a list of 17 urban spaces with sports concentration is obtained (see Table 1) using different sources of information. In a later stage, these 17 areas have been analyzed in greater depth using the previously described phenomenological analysis (conducting face-to-face interviews with sportspeople and the direct observation by technicians in the different places selected). This analysis has allowed to obtain a qualitative information in relation to the attributes and qualities of the optimum urban space to practice sports, the type of activities and new sports, citizen demands for their practices, improvement measures, etc.

The online surveys subsequently carried out among citizens have allowed contrasting the information provided by the Reporting Agents (Table 1). More than $50 \%$ of respondents have confirmed the practice of outdoor sports in any of the areas indicated $(37 \%$ indicated the sea promenade as a place to practice sports, $4.2 \%$ the Teatinos area (zone 18 in Table 1), 4.7\% the Montes of Málaga (zone 17 in Table 1) and 1.6\% the area of the Gualdalmedina river (zone 9 in Table 1 ).

From the identification of urban areas with informal sports activity, their relationship with the areas of the city according to income level and the surface of green areas per inhabitant in each of them has been contrasted (see Figure 3). From this comparison, a relationship is established between the surface of green areas per inhabitant and/or qualified public spaces, income level and level of sports activity. Thus, in the neighborhoods next to the sea promenade, there is a high concentration of informal sports activity, coinciding with high-income neighborhoods (such as neighborhoods in the eastern part of the city, as it can be seen in Figure 3). Urban areas with a high rate of green areas per inhabitant (as in the cases of neighborhoods in the western part of the city, see Figure 3) have a high level of income and moderate sports activity according to mappings made through the use of the digital platform. On the contrary, urban areas with the lowest rate of green areas per inhabitant have a low-income rate and less sports activity according to data recorded through the platform (see Figure 3). These relationships raise a possible lack of equity in access to urban spaces that facilitate sports practice for the population, an issue that should be considered in the planning of urban, social and sports policies. 


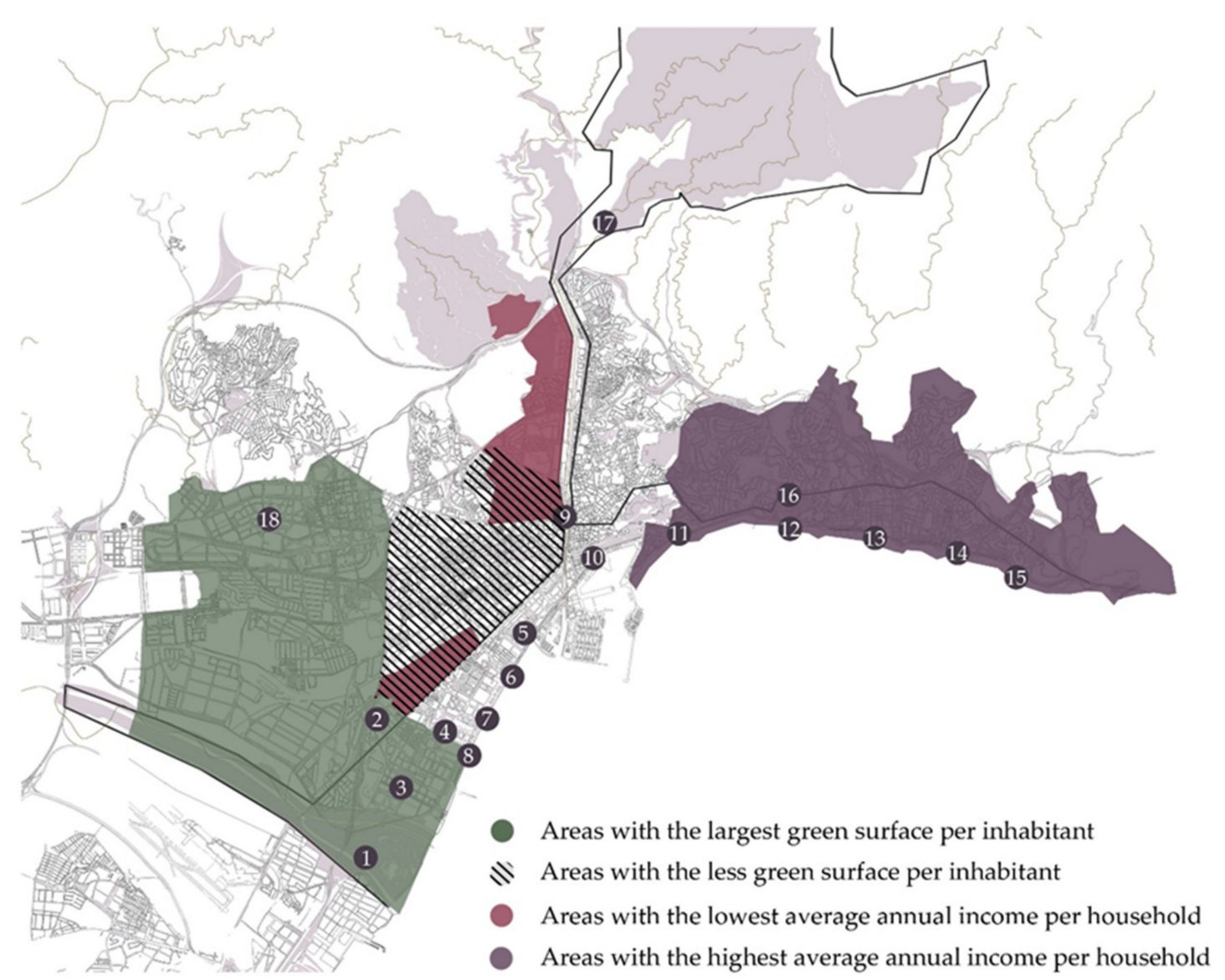

Figure 3. Concentration of informal sport activity, income level and surface of green areas. Source: made by authors from data obtained in Malaga Urban Agenda. Sustainability Indicators, 2016 (link to document) and data provided by Reporting Agents (Table 1).

Likewise, mapping of intensity of sports activity in the city have been developed, distinguishing between formal and informal sports activity (see Figure 4). In relation to formal activity, a balanced and sufficient distribution of municipal sports facilities can be seen in the different neighborhoods, with some exceptions, such as in the eastern part of the city with fewer facilities, which is justified by a lower population density. In relation to informal sports activity, a contrast is observed between those urban areas with a high concentration of informal activity, as in the case of the sea promenade, and other areas with hardly any sports activity, coinciding with low-income neighborhoods and lack of qualified public space. The comparison between the provision of regulated sports facilities and the informal sports areas can be a useful instrument in order to identify urban areas with greater difficulties for practicing sports. 


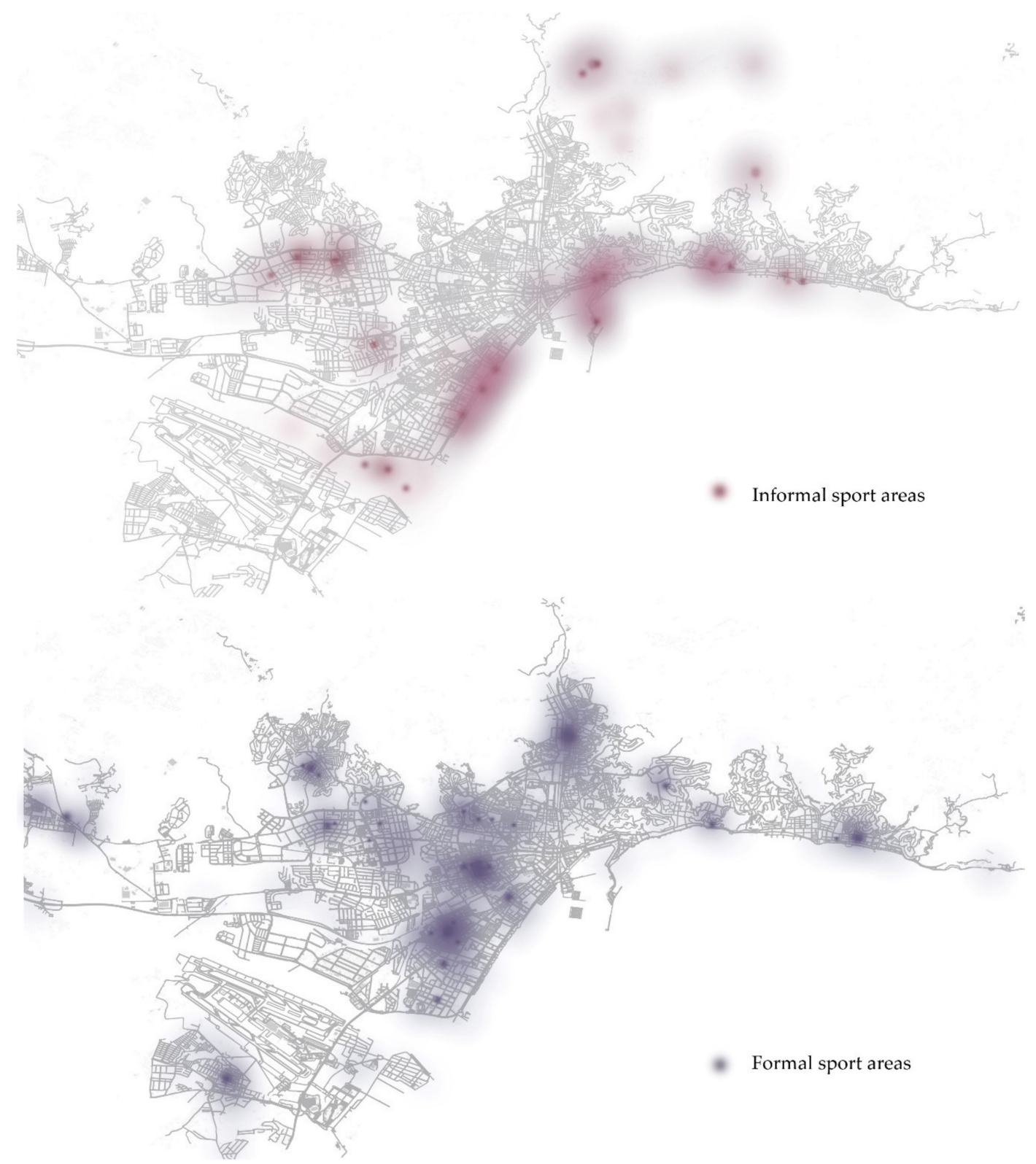

Figure 4. Intensity map of informal and formal sport spaces in the city of Malaga. Source: made by authors from data obtained in the ActivaMálaga platform made within the research project, and online surveys made on citizens, and open-access data about municipal sports facilities from Malaga Townhall.

\subsection{Urban Design and Health. Attributes and Qualities of the Urban Space that Foster Sport Activiy}

Some initial conclusions can be established from all the interviews conducted regarding the characteristics of the urban space that invite the citizens to do sport in a specific place, as shown in Figure 5. A total of 20 face-to-face interviews have been made on people that were doing sport in the public space and 190 interviews online. The following results shown correspond to the online interviews. A total of $40.1 \%$ of the people interviewed were young people aged 15 to 40 , and $55.2 \%$ between 40 and 60 , and the remaining $4.7 \%$ were aged over 60 . It is planned to expand the sample of people online surveys in the development of the research, although the first results obtained offer interesting information as indicated below. 
Security

Large space

Natural environment

Linear space

Close to the place of residence

Close to the workplace

Meeting space with other athletes

Adequate technical conditions

Space without vehicle traffic

Space without annoying noises

Tranquility

Space with rest areas

Close to the study center

Close to the sea (specifically)

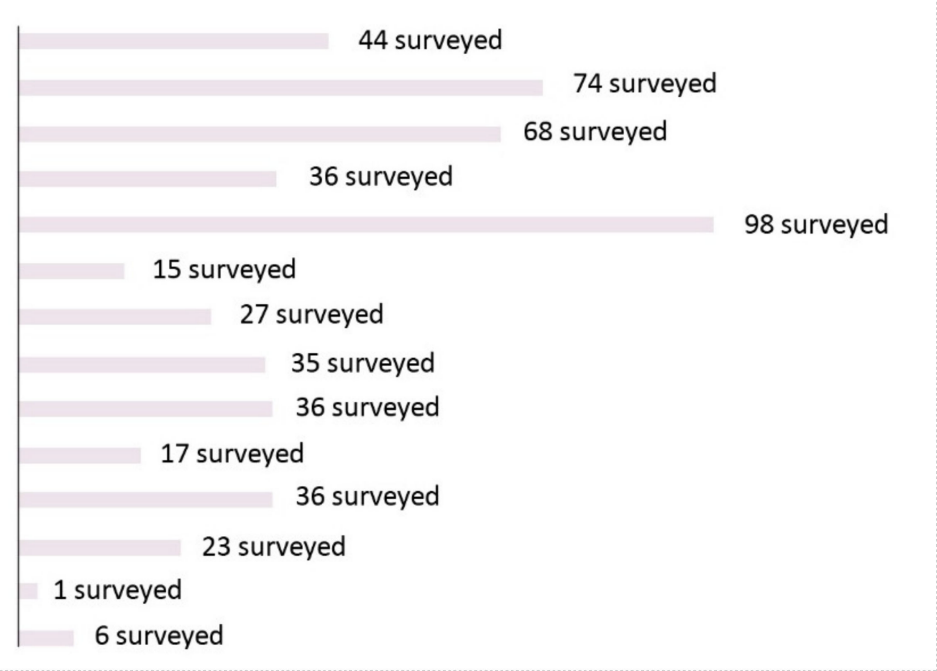

Figure 5. Attributes of the Urban space. Main elements that foster sports activity in the urban space according to the surveyed users. Source: data obtained from the surveys conducted.

Most of the people surveyed have indicated that "proximity to the place of residence" is an important condition for doing sport. In second place, "having a large amount of space for certain activities" has been also highly appreciated. Many people surveyed have chosen "natural environments" and others have highlighted "the need for safe places", the majority of whom have been women. Other conditions that influence the choice of the urban space is "its linearity", "tranquility" and the fact of "having no vehicle traffic". In relation to certain types of sports, "the technical conditions" of the setting are also important criteria for the choice of the place. This information is highly interesting as it allows to know the elements to be considered in order to foster sports activity, and their consideration by local administrations in other urban environments with a poorer state of health, where healthy habits strategies should be implemented.

The condition of large urban spaces, continuous, linear and far from vehicular traffic, justifies the concentration of informal sports activity in the different sea promenades of the city, but also the appearance of sports activity in recently created urban areas, separated from the coastline, where streets have been built with wide sidewalks, a large number of public spaces and many green areas for their inhabitants (as in the cases of Teatinos or Guadalhorce neighborhoods in the western part of the city, see Table 1 and Figure 3). Unlike these, some of the neighborhoods built in the 1970s and 1980s show a deficit of public spaces-invaded by private vehicles as a result of the lack of parking plots in the buildings-and a high population density, such as in the cases low income areas (see Figure 3).

It can be concluded from those first results that the urban environments with the characteristics listed below foster informal sports activity:

- Marine environment: Spaces close to the sea are conducive for the majority of sports.

- Natural environment: they are attractive zones for physical exercise as their environmental quality is high.

- Large parks: as they are natural, accessible and spacious spaces within the consolidated city.

- Linear and wide routes: It can be seen that sportspeople chose a linear route for their sport given that it is therefore easy to set a route.

- Other urban environments called "non places": this term is used to refer to urban spaces with no use or little use, and which certain social groups or urban tribes use for recreational activity, thus giving those places a new identity, as is the case of the course of the River Guadalmedina.

Other information of interest from the surveys, and through the ActivaMálaga digital platform, is focused on establishing the needs to improve the urban spaces for sports practice. This information 
can be very valuable for the authorities in charge of urban design and fostering sport in the city, as it is tool to establish demand in real time. Some of the most common demands of the users are listed below (see Figure 6):

Better paving
Best furniture
Better accessibility
Improvement of sports facilities
Improved feeling of security
Improved lighting
More rest areas
Better signaling
More shady areas
Better cleaning service
Less noise pollution
Better links to bike lanes
Drinking fountains and stretching zones
More and larger exercise areas

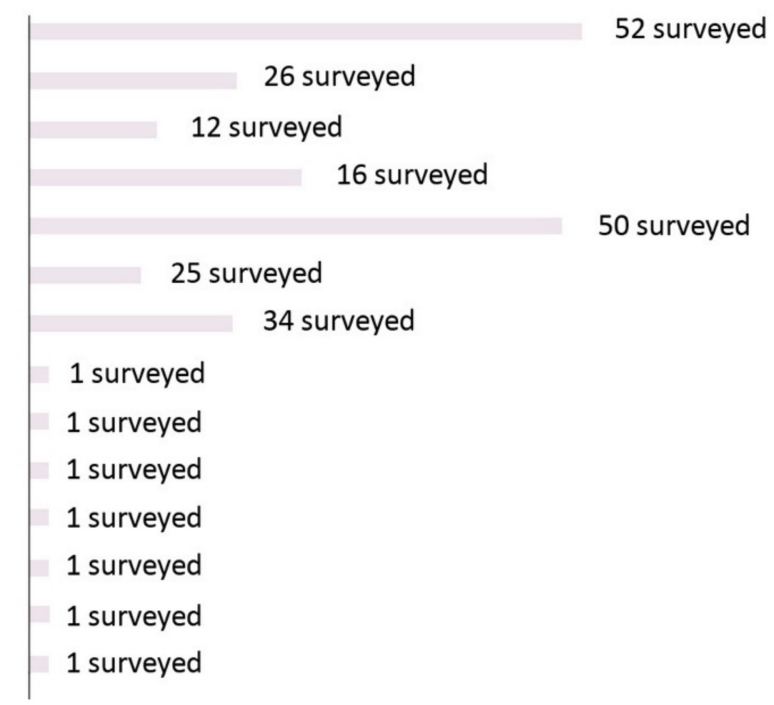

Figure 6. Needs to improve the urban spaces for sports. List of aspects most demanded by users to practice sport in the urban space. Source: data obtained from the surveys conducted.

One of the aspects most stressed by sportspeople is related to feeling safe in the urban space. Mainly women are calling for improvements in this regard. This is of interest for local authorities that should implement a series of actions in this regard: by means of public lighting, for example, in areas earmarked for sports.

"Accessibility" is another of the most rated requirements and, unquestionably, an essential issue, not only to encourage physical activity, but rather to guarantee an inclusive city for everyone. It is important for both the public spaces where the recreational activity takes place, such as ensuring that they are accessible and safe.

Another of the aspects most called for by users has been improving the paving, above all, in relation to running and cycling. It would be of interest to carry out a deeper study into the different types of most suitable paving for the different sports.

As regards improving the street furniture, the surveys conducted revealed some data of interest and which, undeniably, complete the previously collected information (see Figure 7).

More drinking fountains
More benches
More shady areas
Greater number of green areas
More cycle parks
Greater number of stretch zones
Improved lighting
Changing rooms available
More toilets
Sports areas
Mosquito fumigation
More bike lanes
Add electric vehicle lane

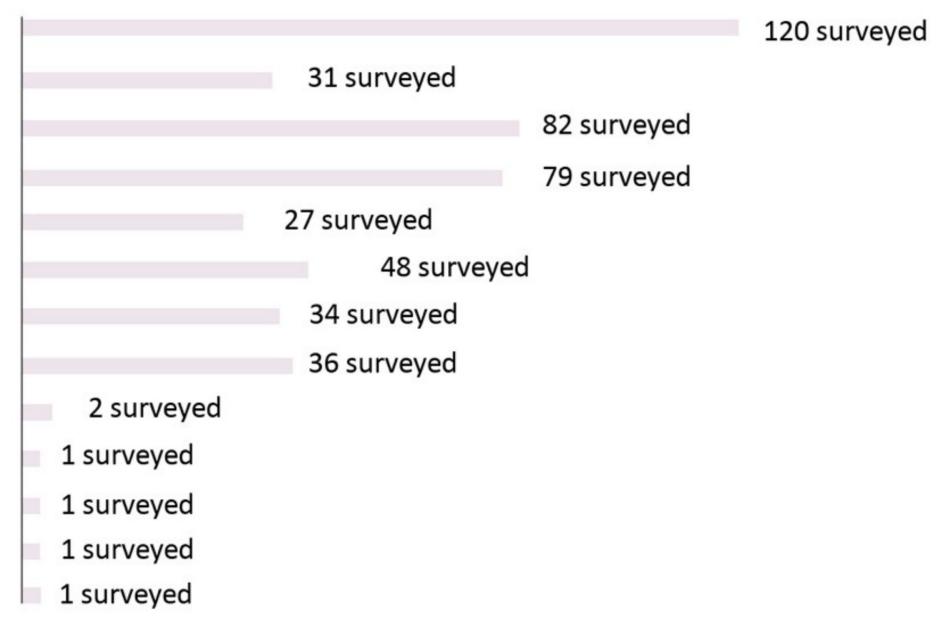

Figure 7. Street furniture. List of most demanded aspects by the people surveyed regarded street furniture. Source: data obtained from the surveys conducted. 
In the case of non-formal public spaces used for sports, the most demanded street furniture are the same as in the case of formal sports: drinking fountains, shady areas and places to park bicycles. Other requests are public toilets and changing rooms for those activities near to the sea or beach.

\subsection{New Trends and Types of Sports}

Finally, special mention should be made of the information gathered with respect to the new types of sports that are emerging in the urban space. Even though many of them are very minority activities, they have been pointed out and mapped, in order local administrations can consider them, and respond to the diversity of emerging activities. The following types of sports have been pinpointed from the 190 replies in the online surveys (see Figure 8).

The first results of the research already show the need for the local authorities to be involved in designing and improving the urban space, including key aspects to incentivize sports on the public space. A total of $88 \%$ of the people surveyed stressed that they would like the city council to adapt the public space for sports, compared to $12 \%$ that asked for no intervention in the existing public space. According to what has been identified in the surveys, it would be of interest to create a document compiling all those informal and formal practices studied in the research aimed at improving the public space for sports, and measures for improvement.

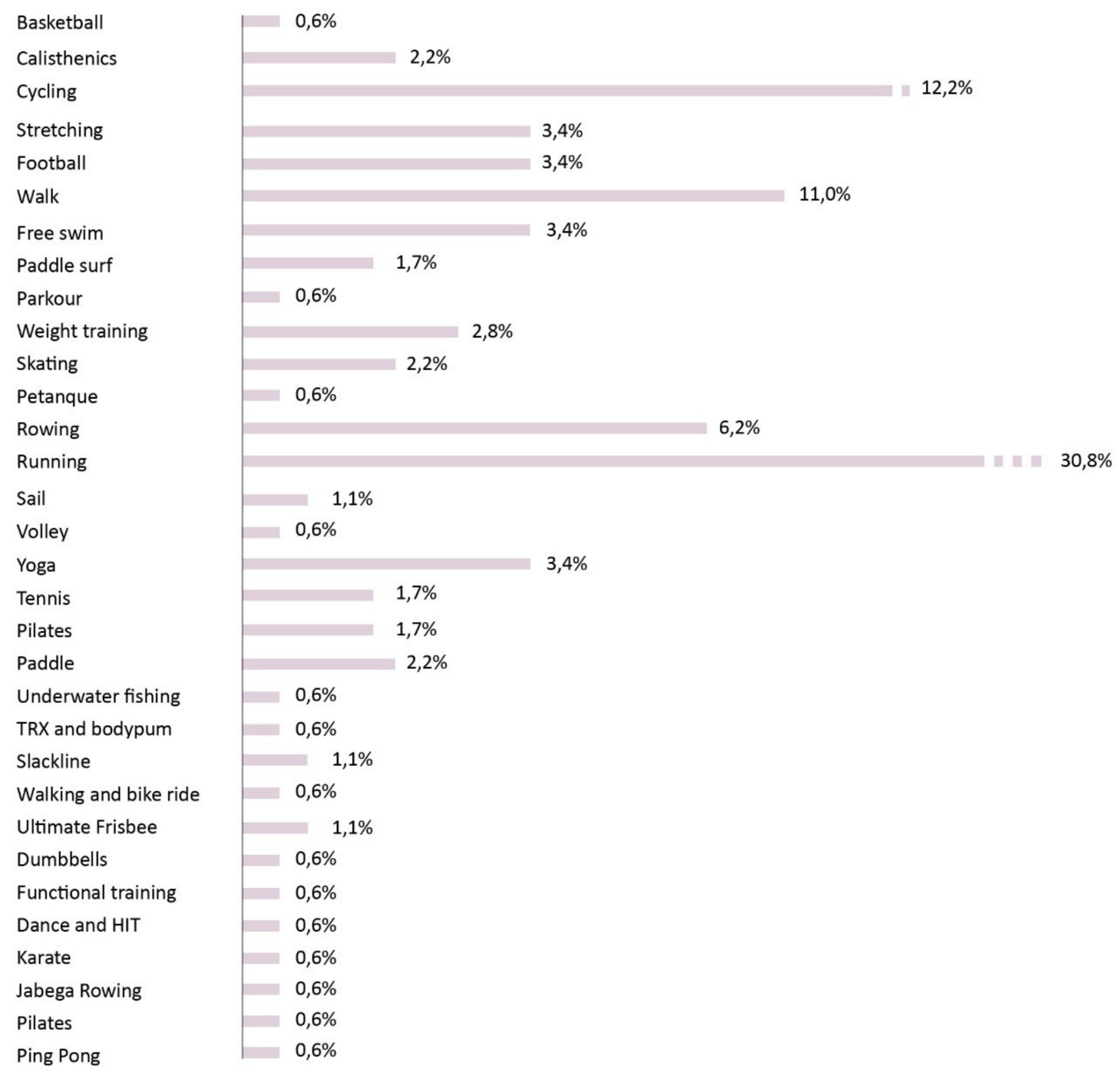

Figure 8. Types of sports. Main sports activities in the urban space of the city Malaga according to surveyed users. Source: data obtained from the online surveys conducted. 


\section{Conclusions}

Previous research in the field of urban planning and active city has noted the need to study the reality of the growing informal practice of sport in our cities. The lack of real specific measurements and records on this informal activity has led to a lack of knowledge about that reality as well as to few urban and sport policies including criteria to foster sports on the public space. The contribution of this research focuses on defining and testing a specific methodology to, firstly, identify and locate, informal sports activity in the city and, secondly, to deepen the study of the attributes of urban space that favor outdoor sports, and citizen demands in relation to requirements of urban space.

The implementation of this approach has shed light on the situation in the city of Malaga, with up to 17 active and healthy urban spaces of informal sports activity being identified. The intensity of sports activity by areas has been compared according to whether it is formal and informal activity. In the case of formal sports practice, an adequate distribution of municipal sports facilities is observed throughout the city with specific exceptions. However, in relation to informal sports, areas of high concentration and others with little sports activity have been detected, establishing a lack of equity between different neighborhoods. These conditions will have to be considered in the planning of urban, social and sports policies by local administrations.

Furthermore, the mapping of informal sport spaces and the development of surveys have allowed to know some of the attributes and qualities of those spaces that are positively valued by local communities: physical attributes, environmental conditions, street furniture's requirements, citizen demands and even sports trends.

In the development of the proposed methodology, the mapping of informal sport spaces, supported by a webGIS digital platform with georeferencing systems, has provided an innovative tool allowing a database to be built in a collaborative way. Citizens have mapped informal sport activity on the public space of the city, and have even, indicated positive aspects about specific areas and demands. The platform itself is a very valuable tool for the local administration to know in real time what is happening in the city in relation to the appearance of informal sports in the city, and to know the demands and requests of citizens. In this regard, the methodology used is positively assessed, even though the number of entries and records of the platform would need to be increased by means of greater dissemination and scope in the number of users.

In addition, it is worth highlighting the value of the information provided by citizens through surveys and even through direct observation by technicians of urban spaces identified as active areas with a concentration of sports activity. This experiential approach allows access to a very valuable type of information from local communities, which should be considered in planning urban and sports policies.

Author Contributions: Conceptualization, N.N.-G.d.S. and A.M.L.-G.; Data curation, M.C.-M.; Formal analysis, M.C.-M.; Funding acquisition, C.R.-J.; Investigation, M.C.-M. and N.N.-G.d.S.; Methodology, N.N.-G.d.S.; Resources, M.C.-M.; Supervision, N.N.-G.d.S. and C.R.-J.; Validation, C.R.-J. and A.M.L.-G.; Writing-original draft, M.C.-M.; Writing-review and editing, N.N.-G.d.S. All authors have read and agreed to the published version of the manuscript.

Funding: Development of research project has been funded by: Network of Strategic Chairs. Malaga City Council-University of Malaga agreement to carry out training programs for the Digital Content Hub (2017/000015). Publication of article has been funded by Research group HUM-969: Urbanismo, Turismo, Paisaje e Innovación Arquitectónica-UTOPIA from University of Malaga.

Acknowledgments: This paper has been prepared based on the results obtained in the "Active Malaga Digital Platform" research project, developed in the collaboration agreement between the University of Malaga and the Malaga City Council "Network of Strategic Chairs to carry out training programs for the Digital Content Hub" (2017/000015). Participating agents: University of Malaga (Chair for Emerging Technologies for Citizenship, Chair for Geo-technological Resources for the Economy and Society, Chair for Interactivity and Design of Experiences); Malaga City Council (Digital Pole, Area of Sport, Municipal Urban Planning Management); Execution of digital webGIS platform: Cartometrics (company hosted by Polo Digital); reporting agents in each sport modality.

Conflicts of Interest: Declare conflicts of interest or state. 


\section{References}

1. Rodríguez, M.B. La importancia de la vitalidad urbana. Ciudad. Rev. Inst. Univ. Urban. Univ. Valladolid 2016, 19, 217-235.

2. Martín, M.C.; de Salazar, N.N.G.; Gil, A.L.; Rosa-Jiménez, C. How new tecnologies can promote an active and healthy city. Digital platform to identify area of informal sport practise in the city of Malaga. In Proceedings of the International Conference on Urban Regeneration and Sustainability, London, UK, 15-17 October 2018; Available online: https://www.ierek.com/events/urban-regeneration-sustainability-2\#publishing (accessed on 2 October 2020).

3. Survey of Sporting Habits in Spain 2015. 2016. Available online: https://www.culturaydeporte.gob.es/dam/jcr: eb913bf1-a897-403b-b056-49b42582ff37/survey-of-sporting-habits-in-spain-2015-synthesis-of-results.pdf (accessed on 2 October 2020).

4. Koohsari, M.J.; Mavoa, S.; Villanueva, K.; Sugiyama, T.; Badland, H.; Kaczynski, A.T.; Owen Neville Giles-Corti, B. Public open space, physical activity, urban design and public health: Concepts, methods and research agenda. Health Place 2015, 33, 75-82. [CrossRef] [PubMed]

5. Coombes, E.; van Sluijs, E.; Jones, A. Is environmental setting associated with the intensity and duration of children's physical activity? Findings from the SPEEDY GPS study. Health Place 2013, 20, 62-65. [CrossRef] [PubMed]

6. Dunton, G.F.; Almanza, E.; Jerrett, M.; Wolch, J.; Pentz, M.A. Neighborhood Park Use by Children: Use of Accelerometry and Global Positioning Systems. Am. J. Prev. Med. 2014, 46, 136-142. [CrossRef]

7. Healthy Urban Development. London. 2019. Available online: https://www.healthyurbandevelopment.nhs. uk/ (accessed on 29 July 2019).

8. ISGlobal-Instituto Salud Global de Barcelona, Planificación Urbana, Medio Ambiente y Salud. 2019. Available online: https://www.isglobal.org/urban-planning\# (accessed on 29 July 2019).

9. Plan Estratégico del Deporte de Valencia. Valencia. 2010. Available online: http://www.fdmvalencia.es/es/lafundacion/documentos-legales/plan-estrategico/ (accessed on 2 October 2020).

10. Plan Director de Instalaciones Deportivas Granada. Granada, Spain. 2010. Available online: http: //www.pmdgranada.es/?seccion=planificacion\&pagina=planlocal (accessed on 2 October 2020).

11. OMS. La Planificación Urbana es Esencial Para la Salud Pública; Website OMS, Ginebra: Mandaluyong, Philippines, 2010.

12. Maza, G. El Espacio Público Como Lugar de Encuentro y Convivencia: El Papel de Lapráctica Deportiva; Diputación de Barcelona: Barcelona, Spain, 2008; pp. 1-6.

13. Magrinyà, F.; Mayorga, M.Y. Diseñar la ciudad para el deporte en los espacios públicos. Apunt. Educ. Fís. Deport. 2008, 1, 102-113.

14. Jacobs, J. Death and Life of Great American Cities; Capitán Sw. Navarra: Pamplona, Spain, 2011.

15. Guel, J. Life between Buildings. Using Public Space; Island Press: Covelo, CA, USA; London, UK, 2011.

16. Kostrzewska, M. Activating Public Space: How to Promote Physical Activity in Urban Environment. IOP Conf. Ser. Mater. Sci. Eng. 2017, 245, 052074. [CrossRef]

17. Manzo, L.C. Beyond house and haven: Toward a revisioning of emotional relationships with places. J. Environ. Psychol. 2003, 23, 47-61. [CrossRef]

18. Vidal, T.; Pol, E. La apropiación del espacio: Una propuesta teórica para comprender la vinculación entre las personas y los lugares. Anu. Psicol. UB J. Psychol. 2005, 36, 281-298. [CrossRef]

19. Rodríguez, J.M.F. La Importancia y la Apropiación de los Espacios Públicos en las Ciudades. Paakat Rev. Tecnol. Soc. 2015, 4, 7. Available online: https://dialnet.unirioja.es/servlet/articulo?codigo=5695440 (accessed on 2 October 2020).

20. Augé, M. Los No Lugares. Espacios del Anonimato: Antropología Sobre Modernidad. 1998. Available online: https://books.google.co.uk/books?hl=zh-TW\&lr=\&id=ESLXDwAAQBAJ\&oi=fnd\&pg= PA9\&dq=Los+No+Lugares.+Espacios+del+anonimato:+Antropolog\%C3\%ADa+sobre+Modernidad\&

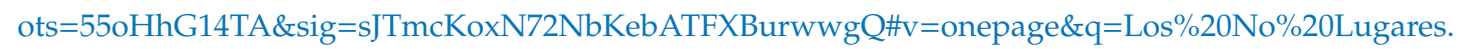
\%20Espacios\%20del\%20anonimato\%3A\%20Antropolog\%C3\%ADa\%20sobre\%20Modernidad\&f=false (accessed on 2 October 2020).

21. Nieto, C. Comunicación alternativa para la movilización ciudadana: Un parque: Mil voces. FISEC Rev. Acad. Iberoam. Estrateg. Comun. 2007, 3, 3-23. 
22. Camino, X.; Pasarello, M.; Puig, N.; Gutiérrez, G.M.; Vilanova, A. Los espacios públicos urbanos y el deporte como generadores de redes sociales. El caso de la ciudad de Barcelona. Apunt. Educ. Fís. Deport. 2006, 30, $76-87$.

23. Misener, L.; Mason, D.S. Developing local citizenship through sporting events: Balancing community involvement and tourism development. Curr. Issues Tour. 2006, 9, 384-398. [CrossRef]

24. Sallis, J.F.; Cerin, E.; Conway, T.L.; Adams, M.A.; Frank, L.D.; Pratt, M.; Salvo, D.; Schipperijn, J.; Smith, G.; Cain, K.L. Physical activity in relation to urban environments in 14 cities worldwide: A cross-sectional study. Lancet 2016, 387, 2207-2217. [CrossRef]

25. Kaczynski, A.T.; Henderson, K.A. Environmental Correlates of Physical Activity: A Review of Evidence about Parks and Recreation. Leis. Sci. 2007, 29, 315-354. [CrossRef]

26. Wheeler, B.W.; Cooper, A.R.; Page, A.S.; Jago, R. Greenspace and children's physical activity: A GPS/GIS analysis of the PEACH project. Prev. Med. 2010, 51, 148-152. [CrossRef]

27. Marselle, M.; Irvine, K.; Warber, S. Walking for Well-Being: Are Group Walks in Certain Types of Natural Environments Better for Well-Being than Group Walks in Urban Environments? Int. J. Environ. Res. Public Health 2013, 10, 5603-5628. [CrossRef]

28. Wolch, J.R.; Byrne, J.; Newell, J.P. Urban green space, public health, and environmental justice: The challenge of making cities 'just green enough'. Landsc. Urban Plan. 2014, 125, 234-244. [CrossRef]

29. Wolf, I.D.; Wohlfart, T. Walking, hiking and running in parks: A multidisciplinary assessment of health and well-being benefits. Landsc. Urban Plan. 2014, 130, 89-103. [CrossRef]

30. Sánchez, M.J.M.; Torné, S.M. Ocio deportivo en los waterfronts de Bilbao y Barcelona. Un estudio comparativo. Rev. Psicol. Deport. 2016, 25, 15-20.

31. Giles-Corti, B.; Timperio, A.; Bull, F.; Pikora, T. Understanding Physical Activity Environmental Correlates: Increased Specificity for Ecological Models. Exerc. Sport Sci. Rev. 2005, 33, 175-181. [CrossRef]

32. Ascione, A.; di Palma, D.; Napolitano, S. Social Inclusion and Education through Sport and Technologies. Sport Sci. 2018, 11, 52-56.

33. Hosseinpour, M.; Terlutter, R. Your Personal Motivator is with You: A Systematic Review of Mobile Phone Applications Aiming at Increasing Physical Activity. Sport Med. 2019, 49, 1425-1447. [CrossRef] [PubMed]

34. Schoeppe, S.; Alley, S.; Rebar, A.L.; Hayman, M.; Bray, N.A.; Van Lippevelde, W.; Gnam, J.-P.; Bachert, P.; Direito, A.; Vandelanotte, C. Apps to improve diet, physical activity and sedentary behavior in children and adoslescents: A review of quality, features and behavior change techniques. Int. J. Behav. Nutr. Phys. Act. 2017, 14, 83. [CrossRef] [PubMed]

35. Gilson, N.D.; Faulkner, G.; Murphy, M.H.; Meyer MR, U.; Washington, T.; Ryde, G.C.; Arbour-Nicitopoulos, K.P.; Dillon, K.A. Walk@Work: An automated intervention to increase walking in university employees not achieving 10,000 daily steps. Prev. Med. 2013, 56, 283-287. [CrossRef] [PubMed]

36. Klenk, S.; Reifegerste, D.; Renatus, R. Gender differences in gratifications from fitness app use and implications for health interventions. Mob. Med. Commun. 2017, 5, 178-193. [CrossRef]

37. Nolasco-Cirugeda, A.; Serrano-Estrada, L.; Ciriquián, P.M. ZARCH: Journal of Interdisciplinary Studies in Architecture and Urbanism; Universidad de Zaragoza, Departamento de Arquitectura: Zaragoza, Spain, 2019.

38. Basset, D.R.; Toth, L.P.; Lamunion, S.R. Step counting: A review of measurement conditions and health-related applications. Sport Med. 2017, 47, 1303-1315. [CrossRef]

39. Case, M.A.; Burwick, H.A.; Volpp, K.G.; Patel, M.S. Accuracy of Smartphone Applications and Wearable Devices for Tracking Physical Activity Data. JAMA 2015, 313, 625. [CrossRef]

40. Kirwan, M.; Duncan, M.J.; Vandelanotte, C.; Mummery, W.K. Design, Development, and Formative Evaluation of a Smartphone Application for Recording and Monitoring Physical Activity Levels. Health Educ. Behav. 2013, 40, 140-151. [CrossRef]

41. He, Y.; Li, Y. Physical Activity Recognition Utilizing the Built-In Kinematic Sensors of a Smartphone. Int. J. Distrib. Sens. Netw. 2013, 9, 481580. [CrossRef]

42. Ketabdar, H.; Lyra, M. System and methodology for using mobile phones in live remote monitoring of physical activities. In Proceedings of the 2010 IEEE International Symposium on Technology and Society, Wollongong, Australia, 7-9 June 2010; pp. 350-356. [CrossRef]

43. Lau, P.W.; Lau, E.Y.; Wong, D.P.; Ransdell, L. A Systematic Review of Information and Communication Technology-Based Interventions for Promoting Physical Activity Behavior Change in Children and Adolescents. J. Med. Internet Res. 2011, 13, e48. [CrossRef] 
44. Fukuoka, Y.; Vittinghoff, E.; Jong, S.S.; Haskell, W. Innovation to motivation-Pilot study of a mobile phone intervention to increase physical activity among sedentary women. Prev. Med. 2010, 51, 287-289. [CrossRef] [PubMed]

45. Arteaga, S.M.; González, V.M.; Kurniawan, S.; Benavides, R.A. Mobile games and design requirements to increase teenagers' physical activity. Pervasive Mob. Comput. 2012, 8, 900-908. [CrossRef]

46. Mora, H.; Pérez-delHoyo, R.; Paredes-Pérez, J.F.; Mollá-Sirvent, R.A. Analysis of social networking service data for smart urban planning. Sustainability 2018, 10, 4732. [CrossRef]

47. Evenson, K.; Wen, F.; Hillier, A.; Cohen, D. Assessing the Contribution of Parks to Physical Activity Using Global Positioning System and Accelerometry. Med. Sci. Sport. Exerc. 2015, 45, 10. [CrossRef]

48. Liao, Y.; Shibata, A.; Ishii, K.; Koohsari, M.J.; Inoue, S.; Oka, K. Can neighborhood design support walking? Cross-sectional and prospective findings from Japan. J. Transp. Health 2018, 11, 73-79. [CrossRef]

49. Istepanian, R.S.H.; Sungoor, A.A.; Faisal, A.; Philip, N. Internet of M-health Things 'm-IOT'. IET Semin. Assist. Living 2011, 2011, 20. [CrossRef]

50. Conroy, D.E.; Yang, C.-H.; Maher, J.P. Behavior Change Techniques in Top-Ranked Mobile Apps for Physical Activity. Am. J. Prev. Med. 2014, 46, 649-652. [CrossRef]

51. Kulawiak, M.; Lubniewski, Z. SafeCity-A GIS-based tool profiled for supporting decision making in urban development and infrastructure protection. Technol. Forecast. Soc. Chang. 2014, 89, 174-187. [CrossRef]

52. Activa Málaga. Plataforma de espacios urbanos deportivos. Available online: https://activamalaga.com/ (accessed on 2 October 2020).

53. Ayuntamiento de Málaga, Equipamientos Municipales y Servicios Deportivos en Concesión Disponibles en la Ciudad. Available online: http://deporte.malaga.eu/espacios-deportivos/instalaciones/ (accessed on 30 July 2019).

54. Strava. Available online: https://www.strava.com/ (accessed on 2 October 2020).

55. Endomondo. Available online: https://www.endomondo.com/ (accessed on 2 October 2020).

56. Gil, A.M.L. El deporte como objeto de reflexi? BAGE 2012, 59, 49-78.

(C) 2020 by the authors. Licensee MDPI, Basel, Switzerland. This article is an open access article distributed under the terms and conditions of the Creative Commons Attribution (CC BY) license (http://creativecommons.org/licenses/by/4.0/). 